\title{
NOTES ON THE GENUS MORMOLYCE HAGENBACH (Coleoptera, Carabidae)
}

by

\author{
M. A. LIEFTINCK and J. T. WIEBES \\ Rijksmuseum van Natuurlijke Historie, Leiden
}

The present memoir contains some notes and observations on the taxonomy and biology of the beetle genus Mormolyce Hagenbach. Though only too well known among coleopterists ever since their discovery, these remarkable carabids do not appear to have been critically studied in recent years. As a matter of fact, very little information on them has been supplied during the last fifty years or so, nearly all observations of more than passing interest being contained in what may be aptly called "classical" memoirs, written by some earlier students whose works are listed in the literature cited at the end of this paper. The present authors, therefore, have gratefully accepted this opportunity to put on record the results of a fresh study of these insects by reviewing the facts already known in a joint attempt to check previous investigations against their own. The junior author has revised the systematics, taxonomy and early stages of Mormolyce, his studies being based on a rich supply of material including specimens and illustrations of great historical interest. To the senior author has fallen the task of establishing some localities with more precision and of narrating on his own experiences with Mormolyce phyllodes Hagenbach while on a collecting trip to the Malay Peninsula, these field notes having, in fact, initiated the studies presently carried out. However fragmentary, the above investigations put together may, it is hoped, contribute in some measure to our knowledge of Mormolyce generally.

Much of the material which forms the basis of this paper is lodged in the Rijksmuseum van Natuurlijke Historie, Leiden. Other specimens were made available for study by the authorities of the British Museum (Natural History), London; the Zoologisch Museum, Amsterdam; and the University Museum, Hope Department of Entomology, Oxford. The writers are indebted to Mr. P. H. van Doesburg Sr., Baarn, for supplying locality records of beetles in his collection, and also to Messrs. M. A. Donk, of the Rijksherbarium, Leiden, and C. A. W. Jeekel, of the Amsterdam Museum, who both gave important information on the nomenclature of bracket-fungi and epizoic Laboulbeniaceae.

\section{DESCRIPTIVE NOTES ON MORMOLYCE PHYLLODES HAGENBACH}

\section{IMAGINES}

Distribution and geographical variation. - The fresh series of Mormolyce phyllodes Hagenbach from Perak (5 $q 4$ ô, Plus River area, Sungei Chior, leg. M. A. Lieftinck, 7.III.1963) forms a welcome addition to the collection of the Leiden Museum, which contained only one specimen from the Asiatic mainland (Central S i a m, Niki, 150 m alt., Kwae Noi River exp., leg. J. E. Jonkers, 23.IV-5.V.1946). Other material in the collection originates from West J a v a (several specimens without exact locality, collected by $H$. Kuhl \& J. C. van Hasselt, S. Müller and $\mathrm{Cl}$. Mulder; and 2 examples from the Preanger, leg. P. F. Sijthoff). The following are from $\mathrm{S} \mathrm{u} \mathrm{m} \mathrm{a-}$ tra: some without exact locality; N.E. Sumatra: 1 ex., E. Atjeh, Gedong Biara, leg. R. Straatman, 4.XII. 1952; 1 ex., Tebingtinggi [Deli, low country], leg. F. J. Weynman; 1 ex., Tandjong Morawa [Serdang distr., low country], leg. B. Hagen. W. Sumatra: 1 ex., Tanangtalu [Ophir distr., $1000 \mathrm{~m}$ alt.], leg. E. Jacobson, V.1915; 1 ex., Soerian, Sumatra exp., I.1878; 1 ex., Solok [Padang distr., $400 \mathrm{~m}$ alt.], leg. P. O. Stolz; 1 ex., Rimbo Pengadang [Benkulen, $1000 \mathrm{~m}$ alt.], leg. E. Jacobson, VI.1916. E. Sumatra: Palembang [low country]. B a ng ka I.: 1 ex., Bangka. N a t u $n$ a Is. [off W. Borneo]: 2 ex., Great Natuna I., leg. A. L. van Hasselt. B or neo: see below.

The three specimens labelled: $\mathrm{K}[\mathrm{uhl}]$ \& $\mathrm{v} . \mathrm{H}[\mathrm{as}-$ selt] - Java, form part of the type series of $M$. phyl- 
lodes Hagenbach, and one male is here designated lectotype.

In the collection of the British Museum (Natural History), London, I have seen typical examples from the Malay Peninsula (Perak, leg. Doherty, Grubauer and Fruhstorfer, one II.1890; and from Ding Ding Is. [off the west coast], leg. H. N. Ridley, 1897); J a v a (leg. Horsfield, 1860, and Bowring, 1863); and S u m a tr a (Benkulen, leg. C. J. Brooks, 1912). The specimens from the Amsterdam Museum are from N.E. Sumatra (Sarang Giting, Serdang distr., 1918) and W. Sumatra (Ampugadang, $120 \mathrm{~m}$ alt., leg. A. de Kock, 1925). For Bornean examples, see below.

Although highly variable in size, $\boldsymbol{M}$. phyllodes in Java, Sumatra, Malaya and Thailand appear to be rather constant in structural characters. Gestro (1875: 886-888) described a variety borneensis from Sarawak. In this form, which should be considered a good species, the lateral margins of the prothorax are very regularly, and rather finely, dentate (fig. 13). The Leiden Museum possesses examples of this species from two localities in W. Borneo, viz. Pontianak and the Schwaner Mts. in the interior; in the Amsterdam Museum there is a specimen from E. Borneo: Sambodjan, N. of Balikpapan.

Gestro also noted the presence of aberrant individuals among those from Borneo and considered these a transitional form between phyllodes and borneensis. In the Leiden Museum this form is represented by specimens from W. Borneo (Pontianak; G. Kenepai, Pondok, leg. J. Büttikofer, I.1894) and the Mahakam River (Borneo exp., leg. A. W. Nieuwenhuis). In the British Museum (Natural History) there is a series from Pontianak, and one example from Njabang (ex. coll. Schneider); and two from Mt. Dulit (Oxford exp.) in Sarawak. The Amsterdam Museum possesses a specimen from Pontianak, and one from Sangasangadalam [E. Borneo, S.W. of Samarinda]. I consider these specimens to represent the Bornean race of Mormolyce phyllodes, which I have great pleasure in naming after Prof. Dr. H. Engel:

\section{Mormolyce phyllodes engeli Wiebes, subspec. nova.}

The shape of the prothorax (fig. 12) is different from both $M$. p. phyllodes (pl. 1) and M. borneensis (fig. 13 ), in that the marginal dentations are rather irregular and not nearly as fine as in $M$. borneensis, and lack the characteristic posterior teeth of $M$. p. phyllodes. In most specimens, the margins of the prothorax are hyaline (indicated in fig. 12 by a dotted line); in some hardly so. The male genitalia are similar to those of $M$. p. phyllodes (fig. $10^{1}$ )).

Holotype is a male from Pontianak ("Bornéo occ. Pontianak. 1898") in the collection of the Rijksmuseum van Natuurlijke Historie, Leiden.

It should be noted that the specimens from the Natuna Islands do not belong to the Bornean form, but to $M$. p. phyllodes.

Sexual dimorphism. - The series from Malaya consists of nine specimens, viz. four males and five females. In this species, the distinction between the sexes is of special interest, and the greater part of Mulder's paper was devoted to this subject. MuLDER (1860: 146), after having discussed the characters mentioned by MANNERHEIM (1837), and basing himself on comparative measurements of one male and one female example, reached the conclusion that there are, in Mormolyce phyllodes, no external characters on which the sexes can be distinguished.

Mulder measured the antennal segments of his two specimens, and found them to be longer in the male in absolute length (the main difference being found in the third and fourth segments), although subequal in their length relative to the length of the head. According to Gestro (1875: 889), in the largest specimens of $M$. phyllodes the length of the third antennal segment is longer than the head, or subequal in length; in large specimens, it is subequal or slightly shorter; in smaller specimens, four-fifths of the head-length; and in the smallest specimens, three-quarters of this length.

In the nine specimens from Perak I do not find any secondary sexual characters. The series shows a positive allometry in the length of the head (measured behind the eyes) and in the total length of the antenna, and a slightly stronger positive allometry in the length of the third and fourth antennal segments (see table 1).

Epizoic fungi. - Two males and one female of the series from Perak show an epizoic flora of Laboulbeniaceae. Graro (1892) described Thaxteria künckeli (= Laboulbenia kuenckelii (Giard) Thaxter), from Mormolyce phyllodes collected in Perak, and this species was later (ThAXTER, 1908: 368) recorded from Sumatra. Our specimens, however, resemble more Laboulbenia palmella Thaxter, described from $M$.

1) In the drawing by JEANNEL (1942: 278, fig. 120), the median lobe is distinctly shorter and more robust, and in this respect is more like our example of $M$. quadraticollis Donckier from Borneo. 
Table 1. Measurements (in $\mathrm{mm}$ ) of nine specimens of Mormolyce p. phyllodes from Malaya

\begin{tabular}{|c|c|c|c|c|c|c|c|c|c|}
\hline & \multicolumn{9}{|c|}{ specimen no. (see plate 1): } \\
\hline & $\begin{array}{c}\leftarrow \\
0 \\
\delta\end{array}$ & 2 & $\begin{array}{c}\text { top rov } \\
\mathbf{3} \\
9 \\
\end{array}$ & $\begin{array}{l}4 \\
\text { 우 }\end{array}$ & $\begin{array}{c}-\rightarrow \\
5 \\
\text { 오 }\end{array}$ & $\begin{array}{l}\leftarrow \\
6 \\
9\end{array}$ & $\begin{array}{c}- \text { bott } \\
7 \\
8\end{array}$ & $\begin{array}{c}\text { m row } \\
8 \\
\delta\end{array}$ & $\begin{array}{l}9 \\
9 \\
9\end{array}$ \\
\hline $\begin{array}{l}\text { Length of: } \\
\text { head behind eyes } \\
\text { pronotum } \\
\text { pronotum and elytra } \\
\text { (along median suture) } \\
\text { antennal segment } 1 \\
2 \\
3 \\
4 \\
5 \\
6 \\
7 \\
8 \\
9 \\
10 \\
11\end{array}$ & $\begin{array}{r}8.0 \\
10.8 \\
33 \\
4.0 \\
0.8 \\
9.0 \\
6.7 \\
2.9 \\
3.4 \\
3.4 \\
3.5 \\
3.4 \\
3.2 \\
4.2 \\
44.5\end{array}$ & \begin{tabular}{r}
9.8 \\
12.0 \\
\multicolumn{1}{c}{38} \\
4.6 \\
1.4 \\
12.2 \\
9.9 \\
3.5 \\
3.8 \\
4.0 \\
3.8 \\
3.7 \\
3.5 \\
4.5 \\
54.9
\end{tabular} & $\begin{array}{r}13.1 \\
16.3 \\
4 \\
47 \\
6.1 \\
1.4 \\
17.1 \\
13.8 \\
4.3 \\
4.8 \\
5.0 \\
4.8 \\
4.8 \\
4.6 \\
5.8 \\
72.5\end{array}$ & \begin{tabular}{r}
14.5 \\
16.0 \\
47 \\
\multicolumn{1}{c}{6.1} \\
1.4 \\
18.9 \\
15.5 \\
4.3 \\
4.8 \\
5.1 \\
5.1 \\
5.1 \\
4.8 \\
5.9 \\
71.0
\end{tabular} & $\begin{array}{r}13.9 \\
16.0 \\
47 \\
6.1 \\
1.6 \\
18.9 \\
15.0 \\
4.6 \\
5.0 \\
5.1 \\
5.0 \\
4.8 \\
4.8 \\
6.1 \\
77.0\end{array}$ & \begin{tabular}{r}
14.6 \\
17.0 \\
\multicolumn{1}{c}{48} \\
6.4 \\
1.4 \\
19.4 \\
15.4 \\
4.5 \\
5.0 \\
5.1 \\
5.1 \\
5.1 \\
5.0 \\
5.9 \\
78.3
\end{tabular} & $\begin{array}{r}15.4 \\
17.6 \\
\\
50 \\
6.6 \\
1.6 \\
19.9 \\
15.2 \\
4.8 \\
5.1 \\
5.4 \\
5.3 \\
5.3 \\
4.8 \\
5.9 \\
79.9\end{array}$ & \begin{tabular}{r}
14.6 \\
17.8 \\
\multicolumn{1}{c}{51} \\
6.1 \\
1.6 \\
20.0 \\
16.2 \\
4.8 \\
5.0 \\
5.3 \\
5.1 \\
5.0 \\
4.8 \\
5.8 \\
79.7
\end{tabular} & $\begin{array}{r}15.5 \\
17.8 \\
\\
51 \\
7.1 \\
1.6 \\
21.6 \\
17.0 \\
5.0 \\
5.3 \\
5.3 \\
5.3 \\
5.0 \\
5.0 \\
6.5 \\
84.7\end{array}$ \\
\hline
\end{tabular}
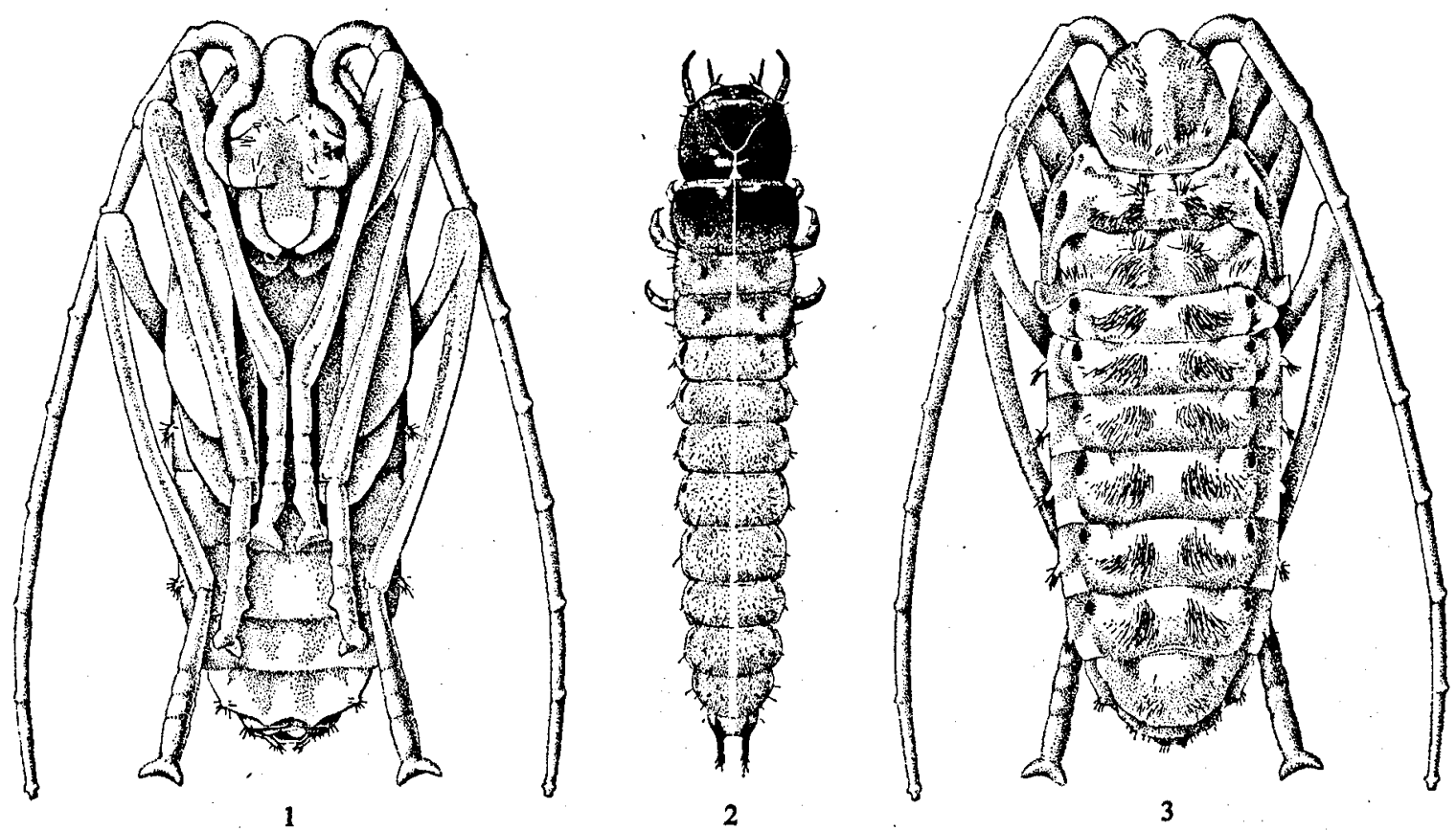

Figs. 1-3. Mormolyce phyllodes Hagenbach. 1, pupa, ventral aspect; 2, larva, dorsal aspect; 3, pupa, dorsal aspect. $1,3, \times 2 \frac{2}{3} ; 2, \times 31 / 3$. 
phyllodes collected in Perak, Molucca ${ }^{2}$ ), and Java (Thaxter, 1895: 337), and later also recorded from Ding Ding Is., Penang, and Sumatra (Thaxter, 1908: 368).

\section{IMMATURE STAGES}

Ver Huell (1847: 344-347, pl. 7 figs. 1-6) described some larvae and pupae collected by Overdijk in Java (see Martuand, 1858: 41). This material soon afterwards was reported lost (MULDER, 1960: 152). Subsequent authors had to base their considerations on the immature stages of Mormolyce on Ver Huell's description and figures, until VaN EMDEN (1942: 20, 81, fig. 18), in his key to the genera of larval Carabidae, described a larva from Sarawak. The present specimens, viz. one larva and one pupa, are compared with the descriptions by Ver Huell and Van Emden, and with some original drawings made by Overdijk, now preserved in the Rijksmuseum van Natuurlijke Historie, Leiden.

Larva. - The larva is about $2.3 \mathrm{~cm}$ long, the width of the head capsule is $3.6 \mathrm{~mm}$. The head-width of Van Emden's larva, considered by him to represent the second stage, measured $3.45 \mathrm{~mm}$, and thus is about of the same size, and presumably age, as the present example. Ver Huell distinguished between a larva "encore très jeune" (fig. 1 of his plate), and one "presque adulte" (his fig. 2), but no measurements were given. If Ver Huell's figures are approximately in natural size, which seems probable, the smaller larva measured ca. $1.5 \mathrm{~cm}$ (head-width, ca. $2 \mathrm{~mm}$ ), and the larger ca. $3.5 \mathrm{~cm}$ (head-width, ca. $4 \mathrm{~mm}$ ). In Overdijk's original drawing, a small scale drawn in pencil next to the figure presumably indicates the total length of the larva: $2.8 \mathrm{~cm}$ (head-width, ca. $4.5 \mathrm{~mm}$ ).

Using VAN EMDEN's (1942: 5-6) calculations of the head-width ratio of the successive stages, and on the presumption that his (as also our) larva represents the second stage, one would arrive at the following approximate values for the head-width of the larvae: I, ca. $2.0 \mathrm{~mm}$ (Ver Huell, pl. 7 fig. 1); II, ca. $3.5 \mathrm{~mm}$ (Van Emden, fig. 18; present larva); and III, 4-4.5 mm (Ver Huell, pl. 7 fig. 2; Overdijk's original drawing).

Here it was assumed that Mormolyce has three larval stages, as is the normal number in Carabidae. It seems to have escaped all authors, however, that Overdijk recorded five moults for Mormolyce phyl-

\section{2) Evidently Malacca!}

lodes in Java: "De Mormolyce leeft als larve 8 à 9 maanden, gedurende welken tijd zij vijfmaal vervelt" 3) (MAITLAND, 1858: 42; repeated by MuLder, 1860: 153). Here the question arises as to the accuracy of Overdijk's observations. Mulder considered the possibility that Overdijk, not being a professional entomologist, may have mistaken the larvae of other beetles for those of Mormolyce. In my opinion, there is little doubt that Overdijk did observe the larvae of Mormolyce well enough to be able to recognize them from others, but, if he did not rear them individually, he may well have been wrong in his reconstruction of the larval cycle.

With the data now at hand, the number of larval stages in Mormolyce cannot be ascertained. VAN EMDEN (1942: 81) mentioned one example of Carabidae in which possibly more larval stages occur than is normal in the family, viz. African Triaenogenius of the tribe Helluonini. It may be of interest to note that this group of beetles (fam. Anthiidae) is related to the Thyreopteridae in which Chaudorr (1868: 133-134), and also recently JEANNEL (1949: 1058), placed Mormolyce Hagenbach. Other Lebiomorphi, as far as known, seem to have three larval stages. Five larval instars were recently described by ERwin (1967) for Brachinus pallidus Erwin, and this abnormal number is evidently related to their ectoparasitoid habits.

The larva (fig. 2) is yellowish in colour, with dark brown parts as follows: the head capsule, the first thoracic segment, patches on the second and third thoraeic segments and on the first abdominal, the peritremata of the spiracles, the cerci and part of the ninth abdominal segment.

The antenna (fig. 9) is four-segmented (length ratio approximately as $12: 10: 11: 7)$, the segments are not "à peu près égales" (Ver Huell: 346); the sensorial appendage of the third segment is cone-shaped, and not very prominent.

The labium (fig. 5) is inverted-trapezoid in outline; the ligula has the shape of a wide triangle, truncate at tip, with a pair of subapical setae and two pairs of laterals; the palpi are two-segmented (12:7), not three-segmented as described by Ver Huell who probably counted the palpigerous portion of the labium as a separate segment (see his figs. 3-4).

The maxilla (fig. 6) has a large stipes, with some antiaxial setae, and a row of setae along the paraxial

3) The larva of Mormolyce lives 8 to 9 months, during which period it moults five times. 


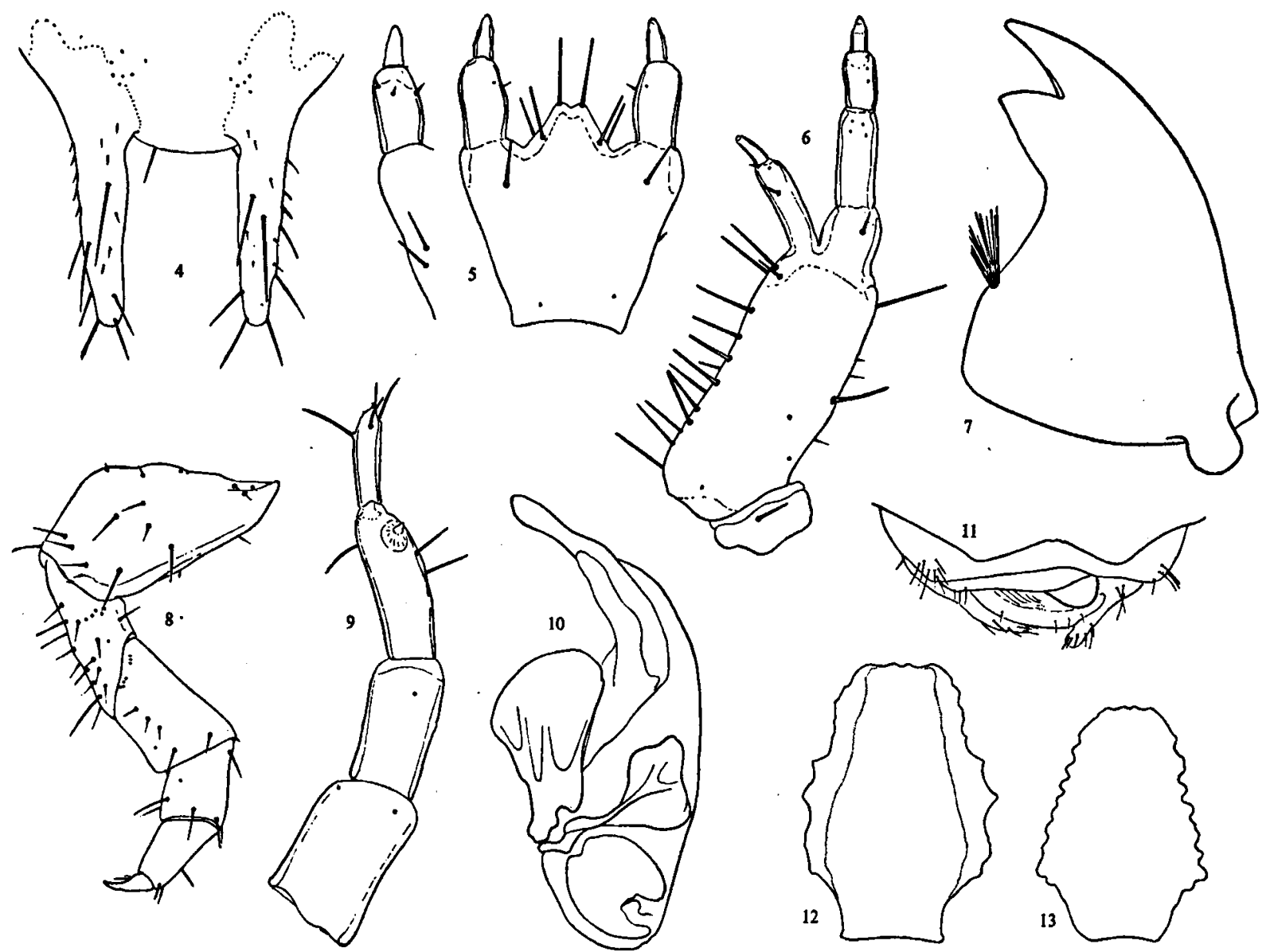

Figs. 4-11. Mormolyce phyllodes Hagenbach. 4-9. larva: 4, cerci, dorsal aspect; 5, labium, ventral aspect, and detail in dorsal view; 6, maxilla, ventral aspect; 7, mandible, ventral aspect; 8 , hind leg, anterior aspect; 9, antenna, ventral aspect; 10, male genitalia, ventral aspect; 11, pupa, apex of abdomen showing male gonotheca, ventral aspect. $4, \times 22 ; 5-7,9, \times 40 ; 8,11, \times 15 ; 10, \times 10$.

Figs. 12-13. Outline of thorax of: 12, Mormolyce phyllodes engeli subspec. nova; 13, Mormolyce borneensis Gestro; $\times 2 \%$.

margin; the palpus is three-segmented (15: $8: 5$; palpiger 10); the outer lobe two-segmented $(7: 3)$, the basal segment indistinctly separated from the stipes. Here again, the relative length of the palpal segments differ somewhat from Ver Huell's description.

The mandible (fig. 7) is robust; it has a strong retinaculum, and a penicillus.

The legs (III, fig. 8) have the normal number of five segments; there is only one claw.

The ninth abdominal segment (fig. 4) is entire, and it bears two slender cerci, not articulated as described by Ver Huell.

In all characters mentioned, the larva agrees with the description by Van Emden, who noted some discrepancies between his larva and the description by
Ver Huell. It would appear that these discrepancies are mainly due to inaccurate observation by Ver Huell, or to his misinterpretation of some structures. In colour, there may be some actual difference between larvae of different stages.

Pupa. - The pupa is ca. $3 \mathrm{~cm}$ long, yellowish; the thoracic terga and the abdominal segments with dorsal and lateral patches of brownish setae; the second to seventh abdominal segments with setose lateral protuberances. See figs. 1, 3.

Ver Huell made mention of a female and a male pupa, and noted some differences in colour and in the number of dorsal setae; but Mulder doubted whether Ver Huell could distinguish between a male and a female pupa (Mulder could notl). The present 
Table 2. Distribution of Mormolyce

\begin{tabular}{|c|c|c|c|c|c|c|c|}
\hline & 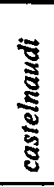 & 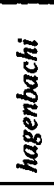 & 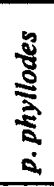 & 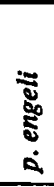 & 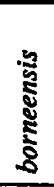 & 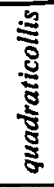 & 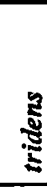 \\
\hline Thailand & & & $x$ & & & & \\
\hline $\begin{array}{c}\text { Malaya (Perak) } \\
\text { Ding Ding Is. }\end{array}$ & $x$ & $x$ & $\begin{array}{l}x \\
x\end{array}$ & & & & \\
\hline $\begin{array}{l}\text { Sumatra } \\
\text { Atjeh (N.E.) } \\
\text { Tebingtinggi (N.E.) } \\
\text { Sarang Giting (N.E.) } \\
\text { Tandjong Morawa (N.E.) } \\
\text { Ampugadang (W.) } \\
\text { Tanangtalu (W.) } \\
\text { Soerian (W.) } \\
\text { Malalak (W.) } \\
\text { Solok (S.W.) } \\
\text { Rimbo Pengadang (S.W.) } \\
\text { Benkulen (S.W.) } \\
\text { Ranau (Benkulen, S.W.) } \\
\text { Palembang (S.E.) }\end{array}$ & $x$ & $\begin{array}{l}x \\
\times \\
x\end{array}$ & $\begin{array}{l}x \\
x \\
x \\
x \\
x \\
x \\
x \\
x \\
x \\
x \\
x \\
x \\
x \\
x\end{array}$ & & & & \\
\hline Java (West) & & & $x$ & & & & \\
\hline Bangka I. & & & $x$ & & & & \\
\hline Natuna I. & & & $x$ & & & & \\
\hline $\begin{array}{l}\text { Borneo } \\
\text { Sarawak (N.W.) } \\
\text { Pontianak (W.) } \\
\text { Njabang (W.) } \\
\text { Sintang (W.) } \\
\text { G. Kenepai (W.) } \\
\text { Sambas (W.) } \\
\text { Schwaner Mts. (C.W.) } \\
\text { Mahakam River (E.) } \\
\text { Sangasangadalam (E.) } \\
\text { Balikpapan (E.) }\end{array}$ & & & & $\begin{array}{l}x \\
x \\
x \\
x \\
x\end{array}$ & $\begin{array}{l}x \\
x \\
x \\
x\end{array}$ & $\begin{array}{l}x \\
x \\
x \\
x \\
x\end{array}$ & $x$ \\
\hline
\end{tabular}

specimen certainly is a male, characterized by the unpaired gonotheca showing between the ninth and tenth abdominal segments (fig. 11).

Specific identification of Van Emden's larva (from Sarawak, leg. Shelford). - Four species of Mormolyce were recorded from Borneo, and two are known from Sarawak (see table 2), viz. M. borneensis Gestro and $M$. phyllodes engeli subspec. nova. SHeLforo (1906: lxxiii) recorded the larvae and pupae of "Mormolyce", and later (1916: 162-163) alluded these to Mormolyce phyllodes. It seems probable that Shelford would have been able to recognize $M$. phyllodes from $M$. borneensis; his specimens then, including the larva described by Van Emden, may have belonged to M. phyllodes engeli.

\section{DISTRIBUTION OF MORMOLYCE IN THE MALAY ARCHIPELAGO}

In total, there are now known to exist six species of Mormolyce, the identification of which may be obtained by reference to Rousseav (1906) and ANDREWES (1941: 315, figs. 1-6). As to the geographical distribution, it can be said that Mormolyce ranges from Central Thailand into Malaysia as far as Java and Borneo. It will be seen from table 2 that the species do not necessarily exclude each other geographically, on the contrary: several instances are known of two or even three species that have been taken simultaneously in one restricted area and obviously may coexist at the same locality. Details of the specific habitations and ethology of each are, of course, unknown but on the basis of the material at our dis- 
posal sympatric occurrences could actually be established and are specified in the table.

The occurrence of Mormolyce phyllodes Hagenbach in Java. - At one time M. phyllodes seems to have been widely distributed in the forests of West Java. The beetle is well represented in collections though the great majority were purchased from dealers and are either labelled "Java" or bear no indication of habitat. This is not surprising as the localities were mostly kept secret. As SHELFord (1916) wrote, in the middle of the last century the Paris Museum actually paid 1,000 francs for a single specimen, "a disbursement which subsequently they must have regretted, for the beetle is by no means uncommon and recently has been taken by the hundred". Now this last statement may refer to some Bornean species, it definitely does not apply to the occurrence of $M$. phyllodes in Java. I know of no collector, expert or dealer, who caught a single specimen during the last fifty years. As far as I am aware the most recent captures were those of the late ornithologist Max Bartels Jr., who shortly before World War II showed me a small series that had been taken in June 1915, by one of the Sundanese mandurs at the tea estate Pasir Datar, on the northwest slope of Mt. Gedeh. Even experienced naturalists like F. C. Drescher, Mrs. M. E. Walsh and E. Jacobson, who spent the best years of their life exploring all parts of Java in company of their native collectors, never once came across the violin beetle. Pictures of Mormolyce that were shown to the Sundanese population in many suitable places, invariably failed to elicit recognition. Therefore it may well be that the insect has since maintained itself only in very limited areas, if it has not already become extinct. In Sumatra and the Malay Peninsula our species has repeatedly been found also in the lowland forests and there is every reason to believe that this was so in Java as well. However, it should be borne in mind that much of the low country in that island, now almost entirely under cultivation, in the early days was occupied by extensive forests unspoilt by human agency but at the same time almost inaccessible. This may account for $M$. phyllodes having been found only at higher levels. Much of the great volcanoes remained well-wooded for a considerable time, the slopes of the Mt. Gedeh-Pangrango complex for instance, were fairly easily attainable by cart or on horseback - to say nothing of the agreeable climate persisting in the submontane zone, which made collecting far more attractive even to the naturalist.

Considering all this, it is very likely that the radical destruction of the hillside vegetation and the deforestation of the great volcanoes in Java are responsible for the disappearance from that island of many insects once common, including Mormolyce.

\section{SOME OBSERVATIONS ON \\ MORMOLYCE PHYLLODES HAGENBACH}

\section{IN PERAK, MALAYA}

The following observations were made in the state of Perak, on the occasion of a long-planned excursion to the Plus River area, a country practically undisturbed by man but well known among naturalists for its luxuriant forests harbouring a rich and varied fauna and flora. The trip had been arranged for me by the University of Malaya at Kuala Lumpur and was undertaken in company with Dr. J. I. Furtado of the same University, our main object being an investigation of the Odonate fauna in the Chior Big Game Forest Reserve, which is within the area mentioned.

We left Ipoh by station car on the early morning of March 7, 1963, heading north via Tg. Rambutan toward the valley of the river Plus, some 35 miles away. A couple of hours later we arrived at kampong Lasah and after having explored for a while the site of the abandoned military camp at the left bank of the river, we crossed the bridge and drove on for another four or five miles following the hill-road which leads up into the Forest Reserve. The surroundings here looked promising enough, so we decided to halt at a suitable spot where we could leave the car and reach the Chior, a tributary of the Plus meandering through heavy forest, almost parallel to our way. There were no tracks leading to this stream but we stopped at a point where the road crossed a tiny brook which seemed to flow in the right direction. With our belongings dangling we slipped down the steep bank into the bed and slowly found our way through the bushes overhanging the water, which was only ankle-deep. It was a bright day with a clear sky, yet under the dense canopy of trees no sunray filtered through the foliage and down here it was very damp and gloomy all around us. After a while I noticed the stem of a huge tree-trunk that had fallen right across the perpendicular banks of the gulley, so as to form a natural bridge. It was a big moss-covered trunk, obviously very ancient, measuring 3 feet across. The underside of the stem was almost two feet overhead so that I could easily pass under it, but what attracted my attention, inciting to a brief inspection, were some "bracketfunguses", of the Polyporaceae, projecting horizon- 
tally from near the under surface of the stem. They were coloured blackish brown on either surface, the species having been identified later as Fomes melanoporus (Mont.) Cooke. There were three of these funguses of different size, two in close proximity of each other and a third, much smaller, about two feet further away. When I came near and looked up to the biggest specimen I suddenly saw a fascinating picture. Facing various directions, their roundish contours hardly discernible in the dim light, I counted five examples of Mormolyce. Here they were, at last, the Violins! Resting upside down with their bodies pressed closely against the underside of the fungus they occupied the entire surface. As soon as I realised that when standing on tiptoe the objects would come just within reach of an outstretched hand, I freed myself from bags and other obstacles and reached out to pick the first beetle by hand $-\mathbf{a}$ gesture which I at once regretted. For all of a sudden I felt as if severely stung in the right eye, by which I was taken aback for quite some moments. This is what had happened. On being disturbed, one of the Mormolyce had emitted a fine spray of some liquid, like an atomiser, and this was volleyed right into my face. As luck would have it, my spectacles served as a shield but obviously had failed to protect my right eye sufficiently. The fluid had a strong scent, resembling a mixture of nitric acid and ammonia. The instantaneous result of this slightly dramatic incident was a choke followed by a coughing-fit, but this was soon over and after a few hours the burning pain also had almost disappeared, although the eye remained sensitive for several weeks.

Meanwhile, after having interfered with my plans, the beetles had come to rest, holding the same position. Using a butterfly net and a knife I then cut off the fungus from the trunk, at the same time shoving its occupants quickly into the net. The insects made no effort to fly away but instead tried to escape by rapidly running away, in which they did not succeed. Having thus obtained all five examples from the biggest fungus, I went on inspecting the two smaller ones, either of which held three more beetles; four of these were captured, two managed to escape. A photograph of the series obtained in this one locality is shown in pl. 1.

As stated above, the largest Fomes was broken off the trunk, cut into two and its contents examined. It had the usual ear-like shape, being about twice as wide as deep, the greatest expanse when freshly cut measuring $310 \mathrm{~mm}$ by a depth of $150 \mathrm{~mm}$, the side of attachment to the trunk having a length of 240 $\mathrm{mm}$. The thickest part of the fungus was, of course, the proximal portion nearest the stem and this proved to be the one inhabited. It had a diameter of only $12 \mathrm{~mm}$ by a depth of scarcely $50 \mathrm{~mm}$, the rest of the plate diminishing rapidly in width towards the free margin, which was only $2-3 \mathrm{~mm}$ thick. Within the woody tissue of the firmest portion of the fungus, just above the porous layer, four nearly equidistant lenticular tunnels of different sizes had been excavated. One of these contained a larva in the penultimate (?) stage, one other yielded a single pupa. These are here figured (figs. 1-3). Fortunately enough, both could be easily recognized by their yellowish white colour as they happened to lie embedded in close proximity to the cutting edge. There were no traces of exit holes leading to these cavities, neither on the firm dorsal surface nor on the softer underside of the Fomes, though the almost black surface beneath was covered with numerous very superficial scratches evidently caused by the adults when crawling about. I had expected at least narrow slits to exist on the porous face, so as to enable the emerging beetle to effect its escape but no orifices communicating with the outside world could be detected. Assuming previous statements about the existence of small holes to be correct, I agree with Shelford (see below) that it is hard to understand how the beetles can free themselves at or after metamorphosis. The only observer who seems to have at all reared the adult insect is C. Overdijk, who in June 1839 found two (freshly emerged?) beetles when unpacking a good quantity of "inhabited" funguses that he had taken home after a two day's search on the eastern slopes of Mt. Gedeh in West Java (Martzand, 1858). Further details are lacking, neither ClaAs Mulder (1860) nor his friend S. Binnendijk, also in Java, actually witnessed the emergence of Mormolyce. Yet Overdijk's original painting of one of his "gammoer" specimens, called Polyporus fomentarius, which is here reproduced (pl, 2), clearly shows scratches and holes described by him in one of his letters. Years later, SHELFORD on two occasions $(1906,1916)$ commented on the same subject by writing as follows:

"Access to the larval chamber is attained by an orifice so small that it is surprising that the newlyemerged beetle can squeeze through it to the exterior, this orifice is situated on the upper surface of the fungus" (1906: lxxiii; the spacing is mine) 4). And later: "I do not know how the imago manages to effect its escape from its prison. I once caught a newly emerged beetle, with the integument still soft and pale in colour, resting on a Polyporus fungus, but though the cell in the fungus was empty it was almost incredible that so large a creature could have 

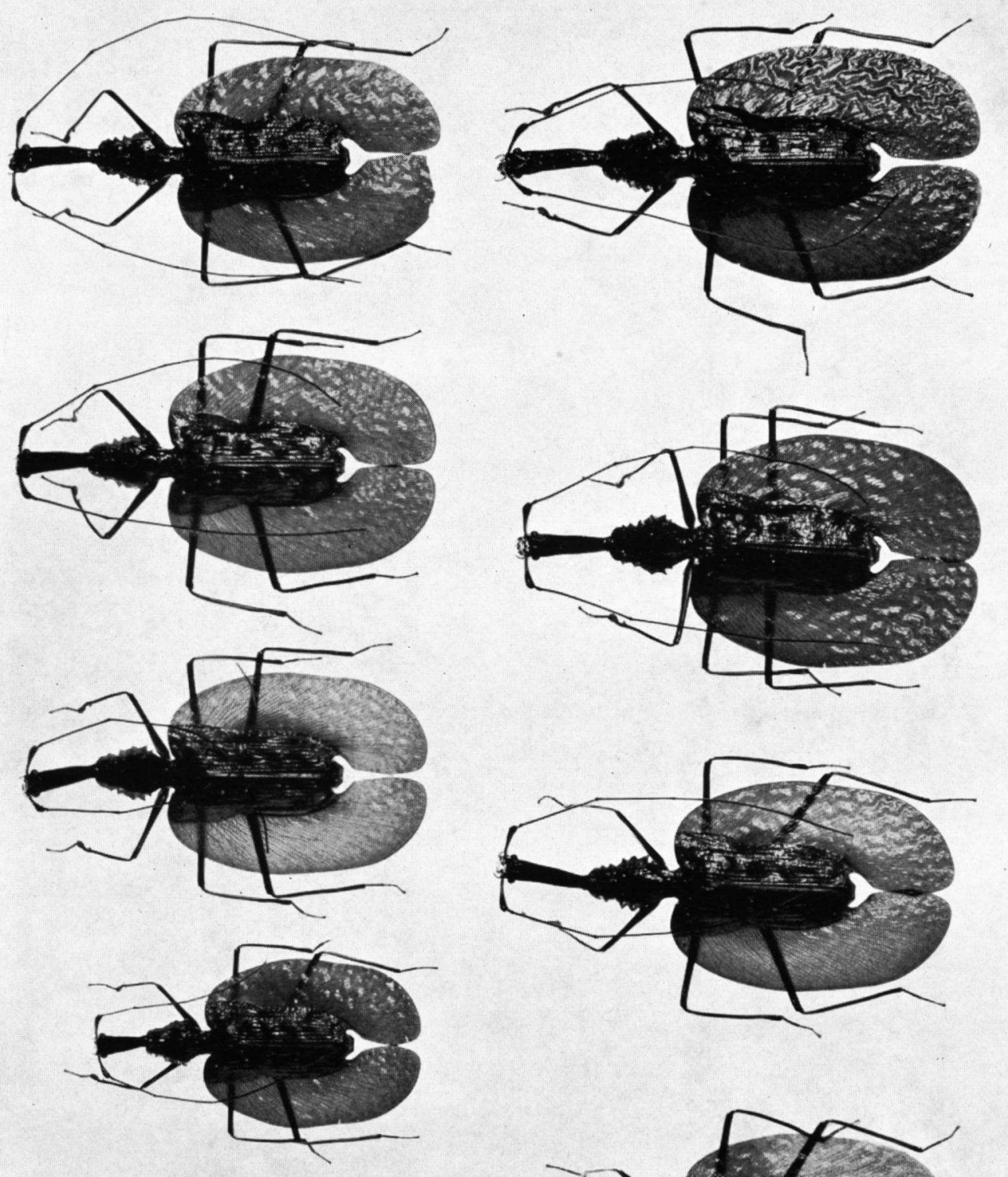

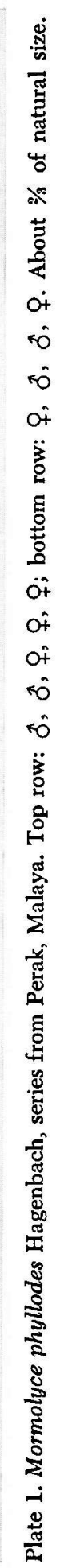



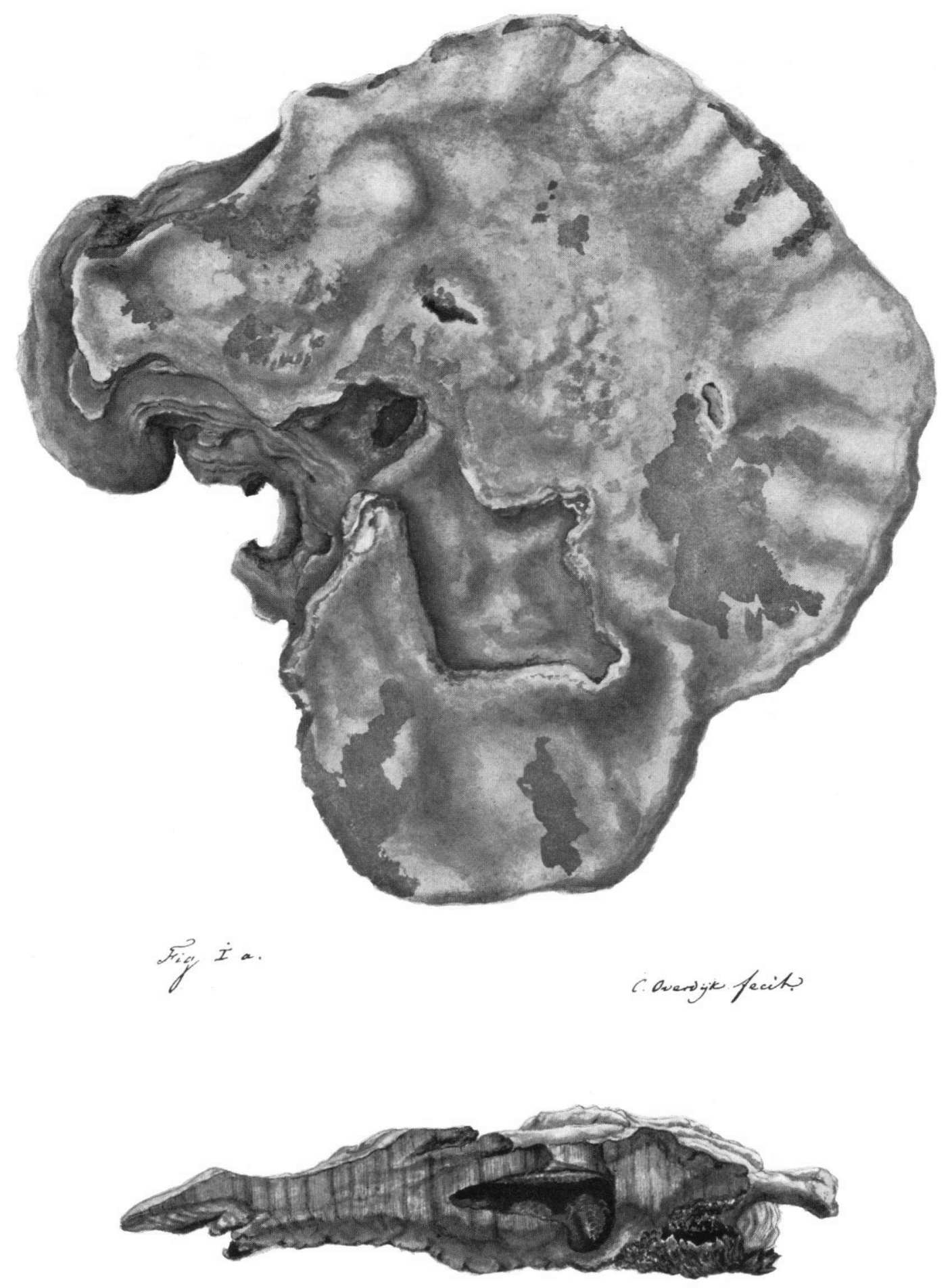

$$
s_{i g}^{2} \dot{1} b
$$

Plate 2. Overdijk's orginal painting of a Polyporacea inhabited by Mormolyce phyllodes in Java. 
escaped through the small hole to the cavity, even allowing for the softness of its tissues, which would, of course, be capable of a certain amount of compression. It is a curious fact that one or more adults are always found in close proximity to a fungus with larval chambers, and I have sometimes wondered if they assisted the newly hatched beetles to emerge by gnawing at the entrance to the larval chamber and increasing its size, but $I$ have never found a fungus showing traces of such action, and so do not consider it probable" (1916: 164). It is just possible to imagine the freshly transformed beetle to leave the fungus by moving towards the bark of the tree and harden its body at some point of attachment. But in the present instance no irregularities whatsoever were to be seen on the edge where this was severed from the trunk. Breeding experiments will therefore be necessary to clarify this point.

There is strong evidence that Mormolyce becomes most active towards dusk and is also attracted by artificial light. Mrs. M. E. Walsh, who in June 1935 was on a collecting trip in southwest Sumatra, told me that one evening she had the good fortune to pick up a specimen that was walking straight into the verandah of the Forestry resthouse at Tandjong Sakti, which is about 500 metres above sea level.

In his little known paper VaN Doesburg (1936) relates on two aspects in the life of adult Mormolyce which are worth mentioning here as they add to our scanty information on the distribution of the genus in Sumatra and on its flight capacities. In the thirties the author received from his correspondent J. J. Th. Boon, at one time a schoolteacher at Ranau, in south Sumatra, seven specimens belonging to three spe-

4) This is a contradictory statement as the same author in his book says that: "... in every fungus that $I$ have examined the one and only entrance to the larval chamber is on the under surface of the fungus" (1916: 163). cies, $M$. phyllodes ( 3 ex.), hagenbachi (2 ex.) and castelnaudi (2 ex.), all in or near the locality just mentioned. One of these, captured by a native, was reportedly taken while nibbling at a tree-fungus, the fungus with its tenant being still in the collection of Mr. van Doesburg. On two occasions the beetles were observed flying about in a forest clearing, once late in the afternoon, the other time in complete darkness, at about 8 o'clock p.m., and in both instances the insects were seen to cover great distances. The observer got the impression that Mormolyce, though being a good flier, has difficulty to take off from the ground and apparently is not capable of doing so until after climbing up some tree. This they can do with great speed and when about to make use of their wings let themselves fall somewhat in the manner of a flying squirrel when sailing down. Mr. van Doesburg's informant also noticed that beetles observed in captivity move about with the long antennae held straight back. On being stimulated to investigate some object, the antennae are turned round in a forward direction, which invariably occurs in the horizontal plane. This habit suggested the beetles to spend most of their life in or between narrowlyspaced, flattened objects.

In connection with the beetles' secretory means of defence, commented upon above, I may again refer to a passage in Overdijk's letter to MaITLAND (1858), in which he complains about the results of having safeguarded his specimens upon homecoming from his excursion. After having touched a couple of newly developed beetles he felt a strong burning itch in his fingers which prevented him from using them for the rest of the day. Shelford (1916), on the other hand, never experienced any ill effects whatever, although he handled several living specimens himself, nor did he ever had complaints from his Dayak collectors who, as he tells, had a still wider experience of living beetles. 


\section{REFERENCES}

Andrewes, H. E., 1941: Papers on Oriental Carabidae. Ann. Mag. nat. Hist. (11) 7, 307-317, figs. 1-6.

Chaudoir, Baron DE, 1868: Mémoire sur les Thyréoptérides. Ann. Soc. ent. Belg. 12, 113-162.

DOESBURG, P. H. VAN, 1936: [Bijzonderheden over het voorkomen van Mormolyce in Sumatra]. Tijdschr. Ent. 79, vii-ix (Verslag 69ste Winter-verg. Ned. Ent. Ver., 23.II.1936)

EMden, F. I. vaN, 1942: A key to the genera of larval Carabidae. Trans. R. ent. Soc. London 92, 1-99, figs. 1-100.

ERWIN, T. L., 1967: Bombardier beetles (Coleoptera, Carabidae) of North America: part. II. Biology and behavior of Brachinus pallidus Erwin in California. Coleopt. Bull. 21, 41-55, photogr. 1-7, pls. 1-3.

Gestro, R., 1875: Note sopra alcuni Carabici appartementi al Museo civico di Genova con descrizione di specie nove. Ann. Mus. Stor. nat. Genova 7, 850-894, figs.

Giard, A., 1892: [Note sur une Laboulbéniacée]. Ann. Soc. ent. France 61, lx-lxi (Bull. ent., séance 24.II. 1892).

Jeannel, R., 1942: La genèse des faunes terrestres. Eléments de biogéographie, i-viii, 1-513, figs. 1-213, pls. 1-8.

- 1949: Quatrième sous-ordre. Adephaga. In: P.-P. Grassé, Traité de Zoologie 9, 1027-1069, figs. 719-752.

Martland, R. T., 1858: [Fragment uit een brief van C. Overdijk over waarnemingen aan Mormolyce phyl lodes]. Tijdschr. Ent. 1, 41-43 (Verslag 13de alg. verg. Ned. Ent. Ver., 4.VII.1857).

MANNERHEIM, LE CoMTE, 1837: Mémoire sur quelques genres et espèces de Carabiques. Bull. Soc. Imp. Nat. Moscou, Année 1837 no. 2, 3-49.

MULDER, C., 1860: Aantekening over Mormolyce phyllodes Hagenb. Tijdschr. Ent. 3, 131-157, pls. 10-11.

Rousseau, E., 1906: Coleoptera. Fam. Carabidae, subfam. Mormolycinae. Gen. Insect. 40, 1-5, 1 pl.

SHELFORD, R., 1906: [Exhibition of the larvae of Collyris emarginatus Dej., and of Mormolyce]. Trans. ent. Soc. London 1905, lxxii-Ixxiii (Proceedings, session 6.XII. 1905).

- 1916: A naturalist in Borneo (edited with a biographical introduction by E. B. Poulton), i-xxvii, 1-331, pls. 1-32.

Thaxter, R., 1895: Contribution towards a monograph of the Laboulbeniaceae. Part I. Mem. Amer. Acad. Arts \& Sci. 12, 189-429, pls. 1-26.

- 1908: Contribution toward a monograph of the Laboulbeniaceae. Part. II. Mem. Amer. Acad. Arts \& Sci. 13, 219-469, pls. 28-71.

Thomson, J., 1862: Monographie du genre Mormolyce. In: Musée scientifique ou receuil d'histoire naturelle, 93-95. [The Musée scientifique ... may be found cited as published in 1860; the paper on Mormolyce bears the following statement: "Le tirage à part de ce travail a paru le 10 août 1862 ".]

Ver Huell, Q. M.-R., 1847: Sur les métamorphoses du Mormolyce phyllodes. Ann. Sci. nat. (3), Zool. 7, 344347 , pl. 7 figs. 1-6. 